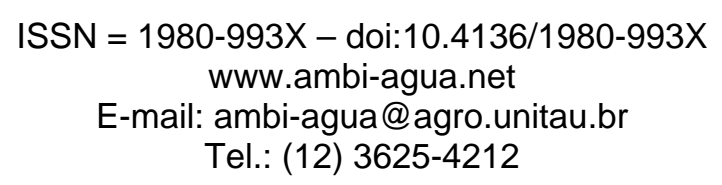

\title{
Applying CSM-CERES-Maize to define a sowing window for irrigated maize crop - The Riacho's Farm case study
}

\author{
(http://dx.doi.org/10.4136/ambi-agua.184)
}

\author{
Tales Antônio Amaral ${ }^{1}$, Camilo de Lelis Teixeira de Andrade ${ }^{2}$, \\ Maria Emília Borges Alves ${ }^{3}$, Denise Freitas Silva ${ }^{4}$ \\ ${ }^{1}$ Biologist, M.Sc. Plant Physiology, D.Sc. Candidate UFPEL, \\ e-mail: tales_aamaral@yahoo.com.br \\ ${ }^{2}$ Agricultural Engineer, PhD Irrigation Engineering, Researcher, Embrapa Maize and Sorghum, \\ e-mail: camilo@cnpms.embrapa.br \\ ${ }^{3}$ Agr. Eng., D.Sc. Agr. Meteorology, FAPEMIG Research Fellow, Embrapa Maize and Sorghum, \\ e-mail: mebalves@hotmail.com \\ ${ }^{4}$ Agr. Eng., D.Sc. Water and Env. Res., CNPq/PNPD Res. Fellow, Embrapa Maize and Sorghum, \\ e-mail: denise@cnpms.embrapa.br
}

\begin{abstract}
Irrigation use constitutes an alternative to improve maize production in Central Minas Gerais State, Brazil. However, even under adequate water supply conditions, other environmental factors may influence maize crop growth and development and may, ultimately, affect grain yield. This study aimed to establish a sowing window for irrigated maize crop, based on simulation results obtained with the decision support model CSMCERES-Maize. Simulations were made for crop management conditions of Riacho's Farm, located in Matozinhos, Minas Gerais State, Brazil. It was employed the model's seasonal tool, along with a data set containing 46 years of weather data records, to simulate maize yield for weekly sowing scenarios, starting on August $1^{\text {st }}$ and ending on July $24^{\text {th }}$ of each year. One defined an irrigated maize sowing window, taking into account the yield break risk that a farmer would be willing to take. The model proved to be an interesting tool to assist in decision making, regarding crop and irrigation management, for an irrigated maize production system. Assuming a 10\% yield break in the expected average maximum maize yield, it was defined as sowing window, the period from January $23^{\text {rd }}$ to March $6^{\text {th }}$, with February $20^{\text {th }}$ as the best sowing date. Other sowing windows may be established according to the risk that the farmer would be willing to take.
\end{abstract}

Keywords: Simulation; crop management; DSSAT; Zea mays L..

\section{Utilização do CSM-CERES-Maize para definição do melhor período para semeadura da cultura do milho irrigado - Estudo de caso da Fazenda do Riacho}

\section{RESUMO}

O uso da irrigação constitui-se numa alternativa para alavancar a produção de milho na Região Central de Minas Gerais. Entretanto, mesmo em condições adequadas de suprimento de água, outros fatores ambientais podem exercer influência sobre o crescimento e o desenvolvimento da cultura do milho, podendo afetar a produção de grãos. Neste trabalho objetivou-se definir uma janela de semeadura para a cultura do milho irrigado, com base em 
AMARAL, T. A.; ANDRADE, C. de L. T. de; ALVES, M. E. B.; SILVA, D. F. Applying csm-ceres-maize to define a sowing window for irrigated maize crop - The riacho's farm case study. Ambi-Agua, Taubaté, v. 6, n. 2, p. 38-53, 2011. (doi:10.4136/ambi-agua.184)

resultados de simulação realizados com o modelo de suporte à decisão CSM-CERES-Maize. As simulações foram feitas para as condições de manejo da cultura na Fazenda do Riacho, localizada no município de Matozinhos, MG, Brasil. Empregou-se o modo sazonal do modelo, juntamente com uma série histórica, contendo 46 anos de registros de dados de clima, para simular a produtividade de milho em cenários de semeaduras semanais, iniciando em 01 de agosto e encerrando em 24 de julho de cada ano. Definiu-se uma janela de semeadura para o milho irrigado, levando-se em consideração o nível de risco de quebra na produtividade que um produtor estaria disposto a correr. O modelo mostrou ser uma ferramenta interessante para auxiliar na tomada de decisão quanto ao manejo da cultura e da irrigação em um sistema de produção de milho irrigado. Assumindo-se uma quebra de $10 \%$ na produtividade média máxima esperada do milho, definiu-se como janela de semeadura o período de 23 de janeiro a 6 de março, tendo 20 de fevereiro como a melhor data de semeadura. Outras janelas de semeadura podem ser estabelecidas em função do risco que o produtor estaria disposto a correr.

Palavras-chave: Simulação; manejo de cultura; DSSAT; Zea mays L..

\section{INTRODUCTION}

The central region of Minas Gerais State has about 60\% deficit in annual corn grain supply, having to import this raw material from other regions. Region's average maize yield is 4,500 $\mathrm{kgha}^{-1}$, with farmers using different technology levels (Agrianual, 2008). Maize can be grown under ample soil and climate conditions. Depending on these factors, producers make decisions, such as sowing date, fertilization rate and irrigation use, in order to reduce risks associated with climate uncertainties and to obtain maximum profits (Kiniry et al., 1997).

Irrigation use may be an alternative to improve production in the region. However, even under adequate water supply conditions, other climate factors such as, solar radiation availability and thermal conditions can influence maize crop growth and development. Yield may not be as high as expected due to these factors (Lozada e Angelocci, 1999). According to Soler et al. (2007) the application of supplemental irrigation should be considered for maize grown off-season, as it can mitigate yield reduction due to both temporal and spatial variability in precipitation. However, other management strategies should also be considered to improve and stabilize off-season maize production. Wilson et al. (1995) emphasize that solar radiation and temperature are key determinants of yield potential for crops grown without biotic and abiotic stresses. A strategy that a farmer can use to get the best yields, under certain climate conditions, is to plant maize at appropriate time. According to Forsthofer et al. (2006), properly selecting sowing date does not affect production cost, but certainly will affect yield and, consequently, farm's profit.

According to Andrade et al. (2009), in general, there are interactions between various factors that affect crop growth, development and yield, whose individual effect is difficult to quantify. Modeling can be a useful tool for studying this kind of problem. The Cropping System Model, CSM-CERES-Maize, one of the models of the Decision Support System for Agrotechnology Transfer, DSSAT (Hoogenboom et al., 2010), can be used to simulate crop growth and development under scenarios of varying climatic conditions and to evaluate management strategies to improve crop yield. The study aimed to use CSM-CERES-Maize to investigate the effect of variable climate conditions on maize yield and to set a sowing window for irrigated maize crop at farm level. 


\section{MATERIAL AND METHODS}

The study was divided into four phases. In the first one, the genetic coefficients for a maize hybrid were derived. In the second phase, the model predictive capability was verified with data from a farm located nearby Embrapa Maize and Sorghum experimental station. Additionally, in that phase, the farmer's irrigation management strategy was also evaluated. In the third phase, model's seasonal module was used to simulate scenarios of sowing dates, in order to define the best planting window for irrigated maize production at that farm. In a fourth phase, the weather elements effect on crop yield for two yield-wide contrasting years was analyzed. In all four phases, the CSM-CERES-Maize version 4.5 (Hoogenboom et al., 2010), was employed. A detailed description of the four phases follows.

\subsection{Model parameterization}

This step of the study was conducted at Embrapa Maize and Sorghum experimental station, located in Sete Lagoas, MG, Brazil, coordinates $19^{\circ} 27^{\prime} 18.37^{\prime \prime}$ South and $44^{\circ} 10^{\prime} 25.25^{\prime \prime}$ West. The single-cross hybrid, DKB 390YG was sown in the field with four replications, in February $20^{\text {th }}, 2009$, in order to collect data for model parameterization. The cultivar was managed under optimum conditions to allow it to express its genetic potential under current weather conditions. Detailed information of model calibration trail can be found in Santana et al. (2010). Data collection and maize genetic coefficients adjustments were done according to procedures described by Hunt and Boote (1998). The statistic d-Stat or concordance index (Wallach, 2006) was used to assess how close to observed data were the simulated results. The closer to unit would be the d-Stat value, the better the simulation quality. Derived genetic coefficients for the hybrid were added to DSSAT's genotype file to be used in other simulations.

\subsection{Model predictive capability and farm's irrigation management evaluation}

In this second phase of the study, the model's predictive capability was verified by comparing simulated with observed maize grain yield. Data for model's verification was obtained at Riacho's Farm, located in Matozinhos, MG, Brazil, coordinates $19^{\circ} 24 ' 32.69^{\prime \prime}$ South and 43 $59^{\prime} 10.34$ " West, 36 km far from Embrapa Maize and Sorghum experimental station.

Daily data, containing 46 years of records, of precipitation, maximum and minimum air temperature and sunshine hours, required by the model, were obtained at Embrapa Maize and Sorghum weather station. Solar radiation was estimated directly by the model using its internal algorithms.

A 45 ha center pivot was used as study area. Samples of soil profile were collected, with replications, to a depth of $1.2 \mathrm{~m}$, for fertility, physical and water retention analysis at Embrapa Maize and Sorghum laboratories. The results, showed in Table 1, were used as input into CSM-CERES-Maize.

The single-cross hybrid DKB 390YG was sown at the 45 ha center pivot area on April $20^{\text {th }}$, 2008, using $0.76 \mathrm{~m}$ row spacing and 70,000 plants per hectare. Crop fertilization consisted of $300 \mathrm{kgha}^{-1}$ of $10-25-16\left(\mathrm{~N}, \mathrm{P}_{2} \mathrm{O}_{5}, \mathrm{~K}_{2} \mathrm{O}\right)$ formula plus zinc, applied in the sowing furrow, and two $75 \mathrm{kgha}^{-1}$ doses of nitrogen as urea, side-dressed at 20 and 30 days after sowing (DAS). All other management practices, such as pest and disease control, were done as recommended for high input maize production system. Supplemental irrigation depths, applied to the crop via center pivot, were recorded by the Riacho's Farm manager. Maize grain yield was recorded by the farm manager. Data files of crop management and of observed yield were prepared. 
AMARAL, T. A.; ANDRADE, C. de L. T. de; ALVES, M. E. B.; SILVA, D. F. Applying csm-ceres-maize to define a sowing window for irrigated maize crop - The riacho's farm case study. Ambi-Agua, Taubaté, v. 6, n. 2, p. 38-53, 2011. (doi:10.4136/ambi-agua.184)

Table 1. Soil fertility, physical and water retention data, for different soil profile depths of the 45 ha center pivot area of Riacho's Farm, Matozinhos, MG, Brazil.

\begin{tabular}{|c|c|c|c|c|c|c|c|c|c|c|}
\hline $\begin{array}{c}\text { Depth } \\
\text { (m) }\end{array}$ & $\begin{array}{l}\text { LLAW }^{1} \\
\left(\mathbf{m}^{3} \mathbf{m}^{-3}\right)\end{array}$ & $\begin{array}{l}\text { ULAW }^{2} \\
\left(\mathrm{~m}^{3} \mathrm{~m}^{-3}\right)\end{array}$ & $\begin{array}{c}\text { Sat }^{3} \\
\left(\mathrm{~m}^{3} \mathrm{~m}^{-3}\right)\end{array}$ & $\mathrm{RGF}^{4}$ & $\begin{array}{c}\mathrm{SHC}^{5} \\
\left(\mathrm{~m} \mathrm{~h}^{-1}\right)\end{array}$ & $\begin{array}{c}\text { Bulk } \\
\text { Density } \\
\left(\mathrm{kg} \mathrm{m}^{-3}\right)\end{array}$ & $\begin{array}{c}\text { Organic } \\
\text { Carbon } \\
(\%) \\
\end{array}$ & $\begin{array}{l}\text { Clay } \\
(\%)\end{array}$ & $\begin{array}{l}\text { Silt } \\
(\%)\end{array}$ & pH \\
\hline 0.15 & 0.293 & 0.435 & 0.515 & 0.950 & 0.0977 & 1550 & 1.54 & 66.5 & 9.5 & 6.6 \\
\hline 0.30 & 0.272 & 0.452 & 0.470 & 1.000 & 0.0786 & 1430 & 1.19 & 67.0 & 10.5 & 7.2 \\
\hline 0.45 & 0.254 & 0.443 & 0.550 & 0.900 & 0.0645 & 1280 & 0.97 & 63.5 & 14.5 & 7.0 \\
\hline 0.60 & 0.240 & 0.411 & 0.584 & 0.300 & 0.2302 & 1200 & 0.88 & 71.0 & 8.5 & 5.4 \\
\hline 0.90 & 0.227 & 0.388 & 0.604 & 0.025 & 0.3719 & 1140 & 0.74 & 67.5 & 11.5 & 5.2 \\
\hline 1.20 & 0.213 & 0.364 & 0.644 & 0.010 & 0.3730 & 1070 & 0.67 & 71.5 & 8.0 & 4.9 \\
\hline
\end{tabular}

${ }^{1}$ Lower Limit of Available Water.

${ }^{2}$ Upper Limit of Available Water.

${ }^{3}$ Saturation.

${ }^{4}$ Root Growth Factor (automatically estimated by the model).

${ }^{5}$ Saturated Hydraulic Conductivity.

In order to evaluate model's predictive capability and farm's irrigation management strategy, the experimental module of CSM-CERES-Maize was set with two treatments: MP Farm's irrigation management. Recorded irrigation depths was used as input into the model; and MA - Automatic irrigation management, considering a $0.30 \mathrm{~m}$ soil profile control depth and $50 \%$ of available water as critical level for soil-water depletion. Irrigation depths were calculated to bring soil water storage to field capacity. It was also considered that irrigation is uniform and that all applied water infiltrates into the soil.

Simulated and observed maize grain yield and cumulated irrigation depth, for February $20^{\text {th }}$, 2008 sowing date, was compared and discussed.

\subsection{Maize yield seasonal and temporal variability analysis}

The third step of this study consisted of applying the CSM-CERES-Maize seasonal tool to evaluate the climate variability and sowing date effects on maize grain yield. The model was set to simulate a virtual experiment containing 52 treatments, which were weekly sowing dates, starting in August $1^{\text {st }}$ and ending in July $24^{\text {th }}$ (Table 2).

Table 2. Treatment identification for virtual seasonal experiment.

\begin{tabular}{c|c|c|c|c|c|c|c|c|c|c|c}
\hline Id $^{1}$ & Date & Id & Date & Id & Date & Id & Date & Id & Date & Id & Date \\
\hline $\mathrm{T} 1$ & $01 / 08$ & $\mathrm{~T} 10$ & $03 / 10$ & $\mathrm{~T} 19$ & $05 / 12$ & $\mathrm{~T} 28$ & $06 / 02$ & $\mathrm{~T} 37$ & $10 / 04$ & $\mathrm{~T} 46$ & $12 / 06$ \\
$\mathrm{~T} 2$ & $08 / 08$ & $\mathrm{~T} 11$ & $10 / 10$ & $\mathrm{~T} 20$ & $12 / 12$ & $\mathrm{~T} 29$ & $13 / 02$ & $\mathrm{~T} 38$ & $17 / 04$ & $\mathrm{~T} 47$ & $19 / 06$ \\
$\mathrm{~T} 3$ & $15 / 08$ & $\mathrm{~T} 12$ & $17 / 10$ & $\mathrm{~T} 21$ & $19 / 12$ & $\mathrm{~T} 30$ & $20 / 02$ & $\mathrm{~T} 39$ & $24 / 04$ & $\mathrm{~T} 48$ & $26 / 06$ \\
$\mathrm{~T} 4$ & $22 / 08$ & $\mathrm{~T} 13$ & $24 / 10$ & $\mathrm{~T} 22$ & $26 / 12$ & $\mathrm{~T} 31$ & $27 / 02$ & $\mathrm{~T} 40$ & $01 / 05$ & $\mathrm{~T} 49$ & $03 / 07$ \\
$\mathrm{~T} 5$ & $29 / 08$ & $\mathrm{~T} 14$ & $31 / 10$ & $\mathrm{~T} 23$ & $02 / 01$ & $\mathrm{~T} 32$ & $06 / 03$ & $\mathrm{~T} 41$ & $08 / 05$ & $\mathrm{~T} 50$ & $10 / 07$ \\
$\mathrm{~T} 6$ & $05 / 09$ & $\mathrm{~T} 15$ & $07 / 11$ & $\mathrm{~T} 24$ & $09 / 01$ & $\mathrm{~T} 33$ & $13 / 03$ & $\mathrm{~T} 42$ & $15 / 05$ & $\mathrm{~T} 51$ & $17 / 07$ \\
$\mathrm{~T} 7$ & $12 / 09$ & $\mathrm{~T} 16$ & $14 / 11$ & $\mathrm{~T} 25$ & $16 / 01$ & $\mathrm{~T} 34$ & $20 / 03$ & $\mathrm{~T} 43$ & $22 / 05$ & $\mathrm{~T} 52$ & $24 / 07$ \\
$\mathrm{~T} 8$ & $19 / 09$ & $\mathrm{~T} 17$ & $21 / 11$ & $\mathrm{~T} 26$ & $23 / 01$ & $\mathrm{~T} 35$ & $27 / 03$ & $\mathrm{~T} 44$ & $29 / 05$ & & \\
$\mathrm{~T} 9$ & $26 / 09$ & $\mathrm{~T} 18$ & $28 / 11$ & $\mathrm{~T} 27$ & $30 / 01$ & $\mathrm{~T} 36$ & $03 / 04$ & $\mathrm{~T} 45$ & $05 / 06$ & & \\
\hline
\end{tabular}

${ }^{1}$ Id = Identification. 
All crop management practices, used at the Riacho's Farm, were considered in the simulations. Irrigation was set to be automatic, as explained before in item 2.2. Embrapa Maize and Sorghum weather data set, containing 46 years of records, was used with model's seasonal tool to generate 46 values of simulated grain yield for each one of the 52 sowing weeks, which were plotted as a boxplot frequency distribution and as average yield values versus variance. The effect of seasonal climate variation and of interannual weather variability on crop yield for different sowing dates was discussed. In addition, a very simple approach (Amaral et al., 2009; Andrade et al., 2009), was used to assist in defining a sowing window for irrigated maize. The procedure consists in determining the percent yield break for each sowing date, by comparing the current average yield with the highest one along the year. This way, the decision-maker would choose the sowing window taking into account the yield break level he or she would be willing to accept.

\subsection{Climate thermal conditions effect on crop yield}

The interactions between maize crop grain yield and weather conditions, for two years that provided the highest and the lowest yields were selected for analysis. Temperature effects on crop thermal sum and, consequently on crop cycle and indirectly on crop yield were considered.

\section{RESULTS AND DISCUSSION}

Results discussion followed the structure of material and methods item, which was divided into four phases.

\subsection{Model calibration}

Observed crop yield of 8,220 kgha-1 ${ }^{-1}$ obtained in the calibration trial (Figure 1), is within the expected range for DKB 390YG cultivar. Average yields varying from 7,877 to 10,129 $\mathrm{kgha}^{-1}$ were reported by Cruz et al. (2005; 2009), for the same hybrid grown under different cropping technology levels. According to the cultivar developer, expected yield for DKB 390YG in Central Brazil would vary from 8,659 to 8,414 $\mathrm{kgha}^{-1}$ (Dekalb, 2010).

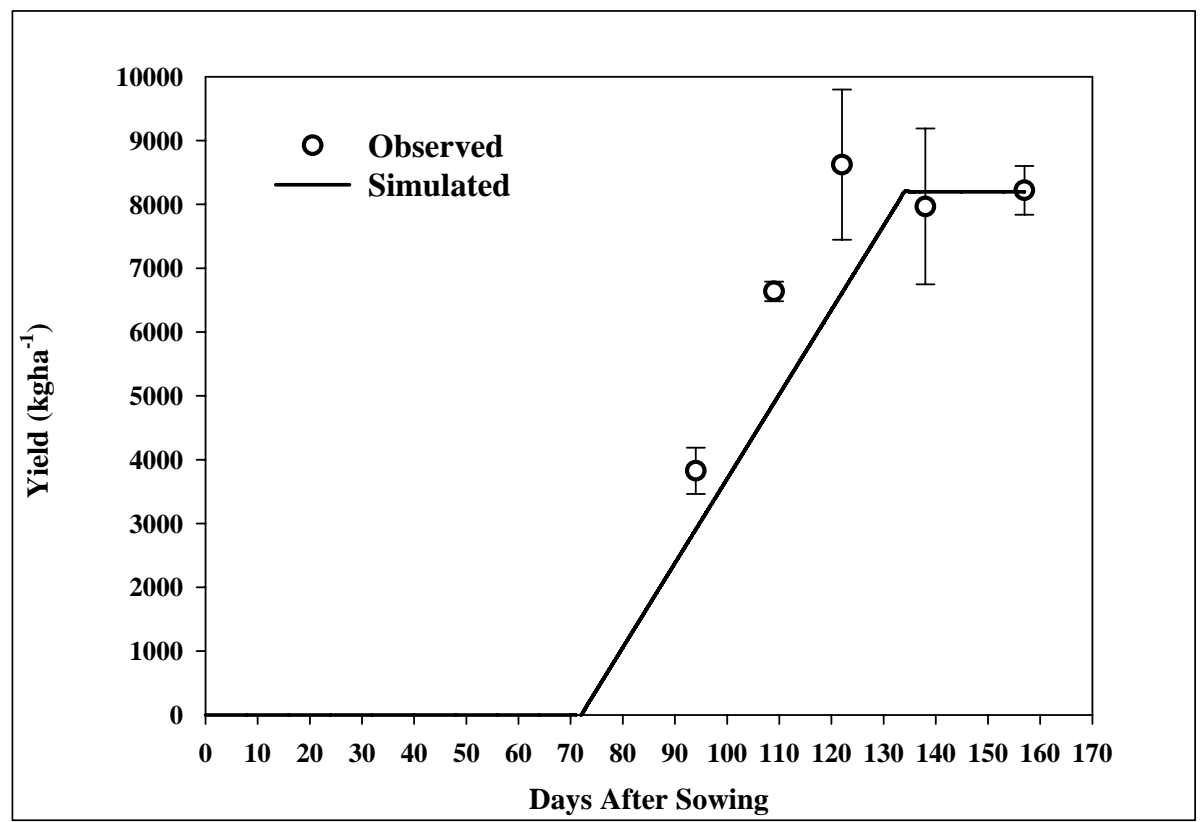

Figure 1. Simulated and observed grain yield after calibration of genetic coefficients for single-cross hybrid DKB 390YG. Vertical bars are mean standard error above and below average. Sete Lagoas, MG, Brazil. 
Aboveground biomass and leaf area index values (Figures 2 and 3) are similar to those reported in the literature for different maize genotypes, grown in other regions, under different conditions (Bergonci et al., 2001; Kozlowski, 2002; Silva et al., 1999). Some discrepancies verified in measured data are due to typical variability observed when plants are sampled, each time at different location in the field trial. Mean standard errors, obtained from sample with three replications indicated that measured values were representative of field observations (Figures 1 to 3). Although the calibration process, forces the model to correctly simulate certain traits, such as, silking and physiological maturity dates and grain yield, other parameters, such as, leaf area index (LAI) and biomass data, collected throughout crop cycle, provide a mean to assess simulation quality. The model tended to underestimate grain dry mass (Figure 1) and aboveground biomass (Figure 2) in crop stages prior to physiological maturity, although the final values were well simulated. The d-Stat statistic was 0.869 for grain yield and 0.989 for the aboveground biomass production, indicating good agreement between simulated and observed data throughout crop cycle (Figures 1 and 2).

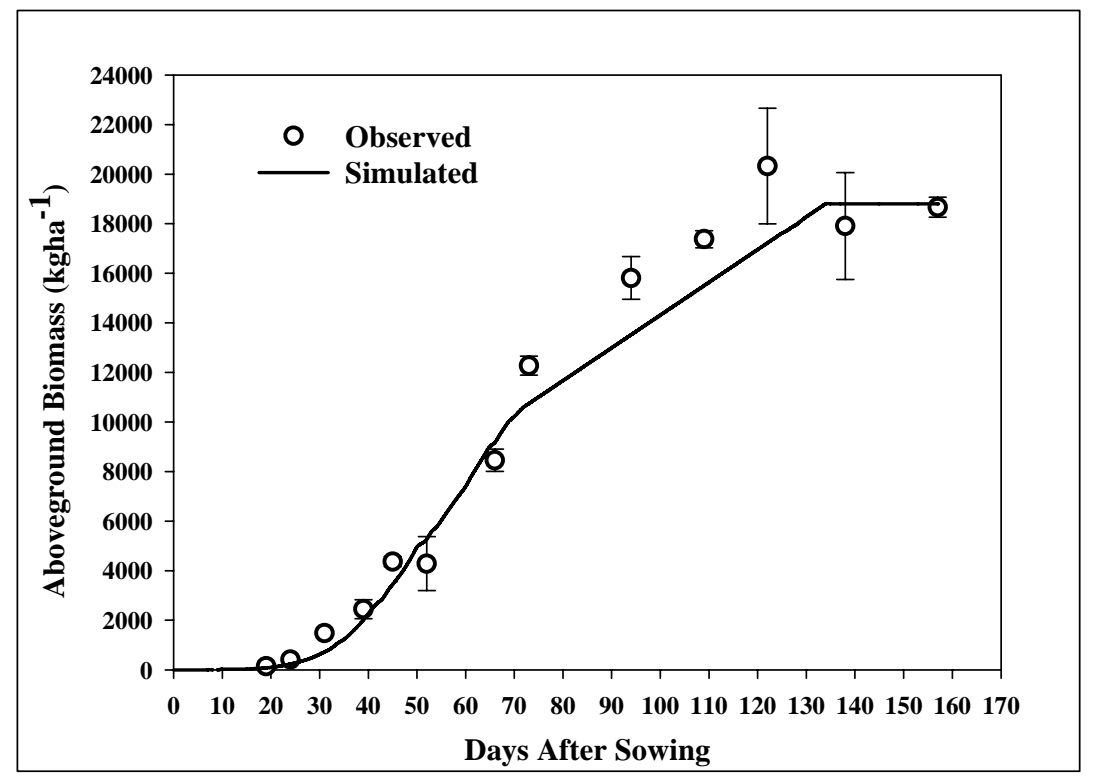

Figure 2. Simulated and observed aboveground plant biomass dry weight for single-cross hybrid DKB 390YG. Vertical bars are standard error above and below average. Sete Lagoas, MG, Brazil.

In spite of the variability in measured leaf area indices (LAI), the general data trend throughout crop cycle is correct. Although, overall simulated figures agreed well with measured values, one can note that the model overestimated leaf area at the final crop stage (Figure 3). The d-Stat index for LAI was 0.858 , indicating reasonable agreement between simulated and observed values.

\subsection{Model predictive capability verification and irrigation management evaluation}

The average grain yield, expressed in dry mass, reported by the farmer for April $20^{\text {th }}$, 2008 growing season at the 45 ha center pivot area, was 7,743 $\mathrm{kgha}^{-1}$ (Figure 4). Simulated yields were 6,896 and 7,239 $\mathrm{kgha}^{-1}$, respectively, when using farm's recorded irrigation data (MP) and automatic irrigation management feature (MA). The CSM-CERES-Maize model underestimated maize yield at $10.94 \%$ when MP was used and at $6.51 \%$ when MA was employed. The agreement between simulated and recorded maize harvested grain yield values was reasonable, considering all the inaccuracies involved in field works, especially at farm level, and in model's process mathematical description simplifications. 


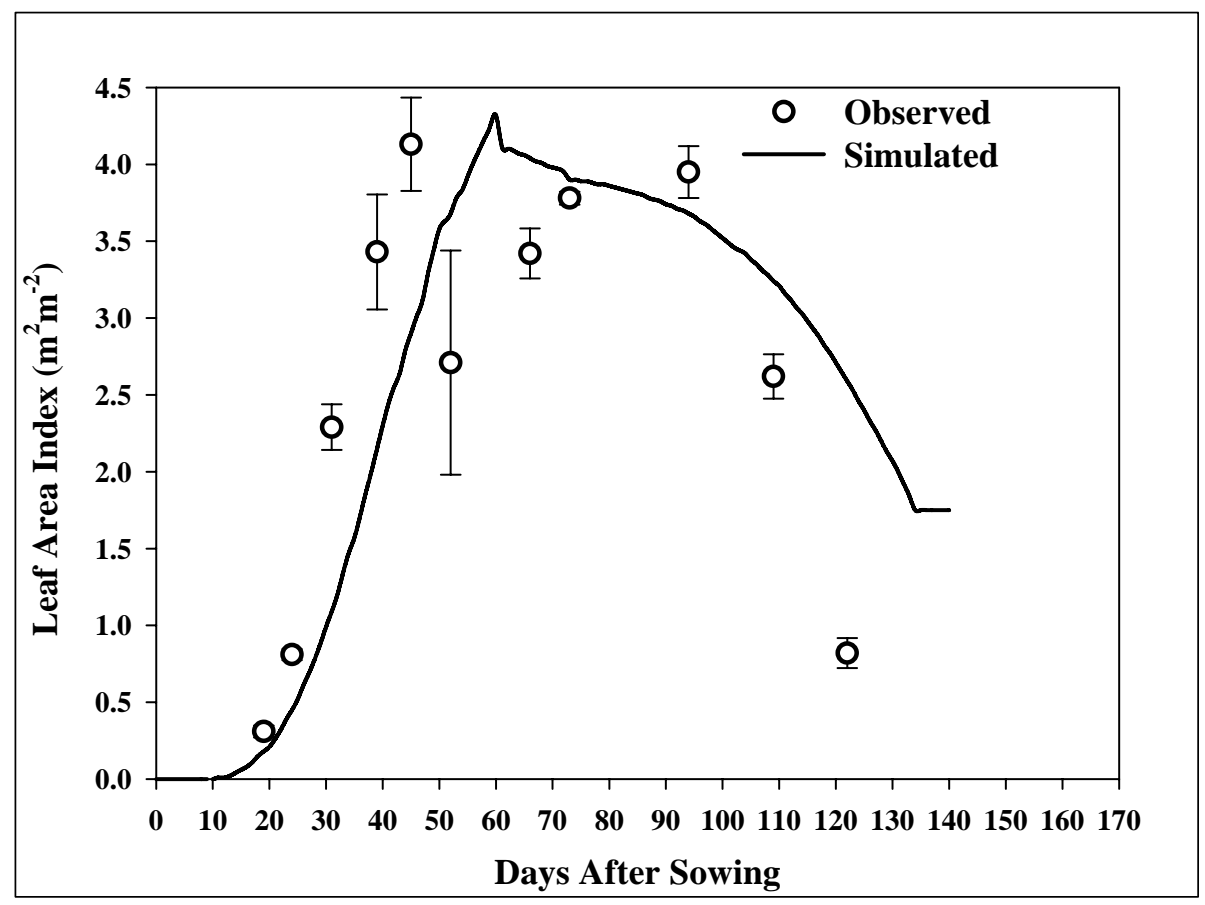

Figure 3. Simulated and observed leaf area indices (LAI) for single-cross hybrid DKB 390YG. Vertical bars are mean standard error above and below average. Sete Lagoas, MG, Brazil.

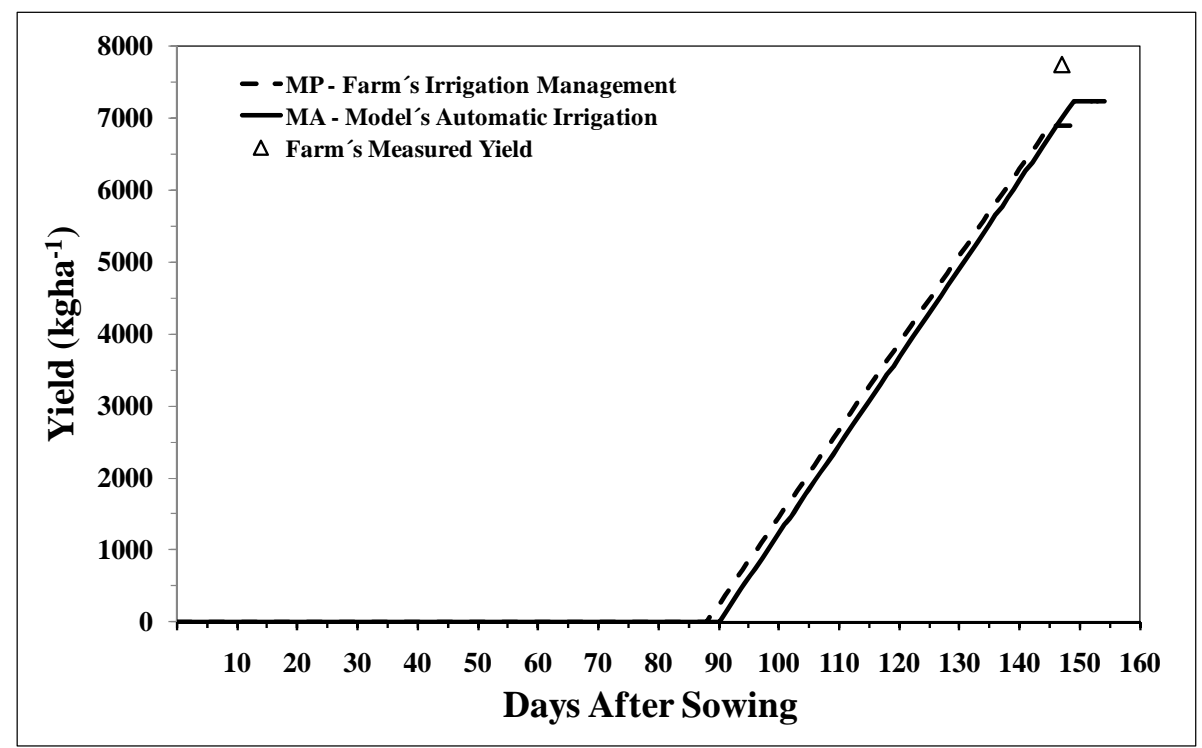

Figure 4. Simulated maize grain yield for two irrigation management strategies and observed harvested grain yield for a 45 ha center pivot area of Riacho’s Farm. Matozinhos, MG, Brazil.

By comparing simulated and observed data from calibration and verification phases, one can consider that overall the model is correctly describing the biophysical processes involved in growth, development and seed production, and can be used to simulate other scenarios of maize crop management. It is worth to mention that the calibration trial was carried out in 2009 and the Riacho's Farm data used for model's validation was obtained in 2008 cropping season. This means no problem regarding modeling, which can capture genotype versus environment interactions irrespective of time. 
Accumulated applied irrigation depth, recorded by the Riacho's Farm manager for April $20^{\text {th }}, 2008$ maize season was $419 \mathrm{~mm}, 15.42 \%$ greater than the $363 \mathrm{~mm}$ simulated by the model with automatic irrigation management (Figure 5). As there was no instrument at the farm to monitor weather and soil-water conditions, so that crop water requirement and irrigation startup could be determined, irrigation was managed based on past manager's experience, which leaded to more frequent applications and overirrigation along crop cycle. From 8 to 100 days after sowing (DAS) excess irrigation summed up to about $200 \mathrm{~mm}$, corresponding to more than double the amount required by the crop at that period. Irrigation was cut at 99 DAS, somehow, earlier than the 144 DAS that would be recommended, as simulated by the model (Figure 5), inducing the crop to shorten its cycle.

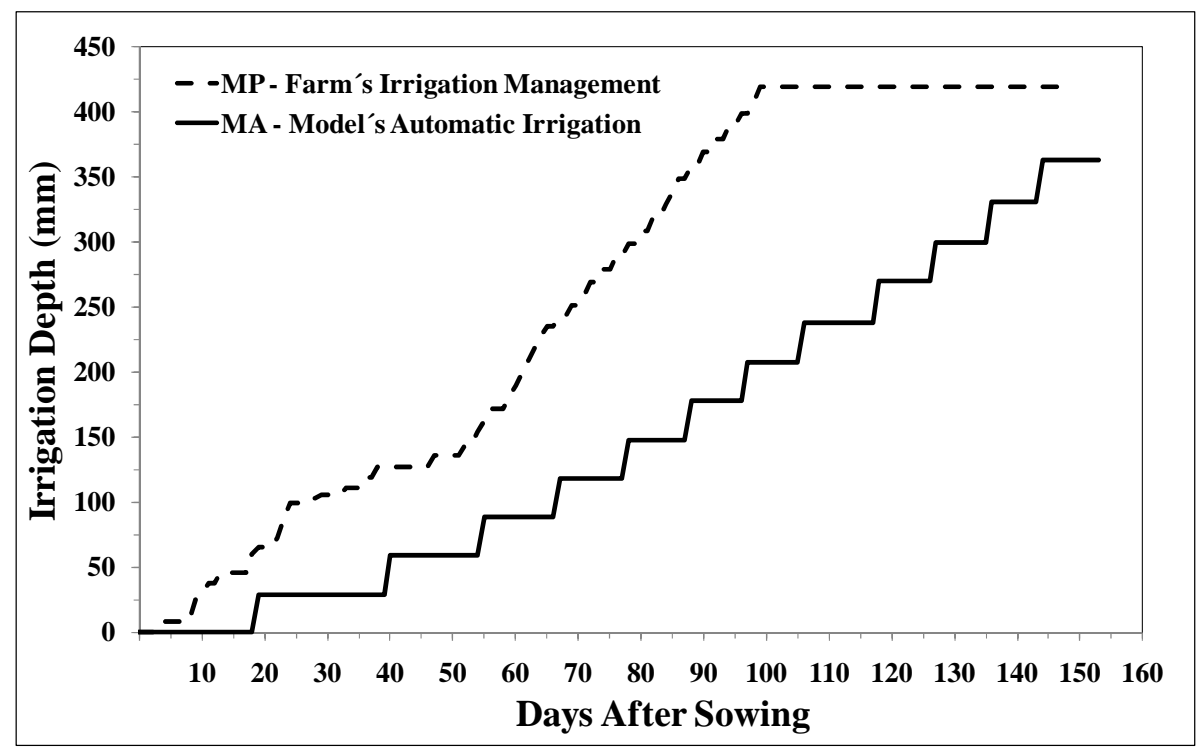

Figure 5. Accumulated irrigation depth recorded at the farm (MP) and simulated by the model using its automatic irrigation feature (MA), along maize cycle at Riacho's Farm. Matozinhos, MG, Brazil.

Farm's recorded crop cycle, from sowing to physiological maturity, was 149 DAS as compared to 154 DAS simulated. The difference between observed and simulated maize crop cycle is because CSM-CERES-Maize stages length determination is based on thermal-time and does not take into account water stress effects.

The anticipated irrigation suspension, at grain filling phase, imposed to the crop some water stress that shortened its cycle and reduced yield. Maize grain yield simulated by using model's automatic irrigation feature, MA, was 4.97\% higher, as compared to that simulated by using farm's recorded irrigation depths, MP. According Kasele et al. (1994), maize is relatively tolerant to drought during the growing season, but it shows extreme sensitivity with decrease in grain yield, if the drought occurs during flowering and grain filling.

\subsection{Maize yield seasonal and temporal variability analysis}

Selecting a suitable sowing window is a crop management strategy that is costless to the farmer but, under varying climate conditions, it allows improvement on yield stability. In this case, environmental elements such as, solar radiation and air temperature can be more efficiently used for crop production. By analyzing model's seasonal tool outputs, charted as frequency distribution boxplots, one can observe a large seasonal an interannual variability in maize grain yield, even under a non-stressed management condition. This is an indication that other climate elements, such as solar radiation and air temperature are as important as precipitation for maize production in the region (Figure 6). 
Looking at a certain sowing date, one can note considerable amplitude in simulated grain yield values, as a consequence of great variability of weather elements amongst the 46 years of recorded data, used in the simulations. In addition, one can also observe a significant seasonal variation in median yields. The highest median value of 9,096 kgha-1 occurred in February $20^{\text {th }}$ sowing date. For this same planting week, in $25 \%$ of years, when weather conditions were not adequate, maize yield ranged from 6,585 to 8,463 $\mathrm{kgha}^{-1}$. On the other hand, one every four years, on which reigned in more favorable climatic conditions, yield varied from 9,495 to $10,872 \mathrm{kgha}^{-1}$. In $50 \%$ of the years, yield ranged from 8,463 to 9,495 kgha $^{-1}$ (Figure 6).

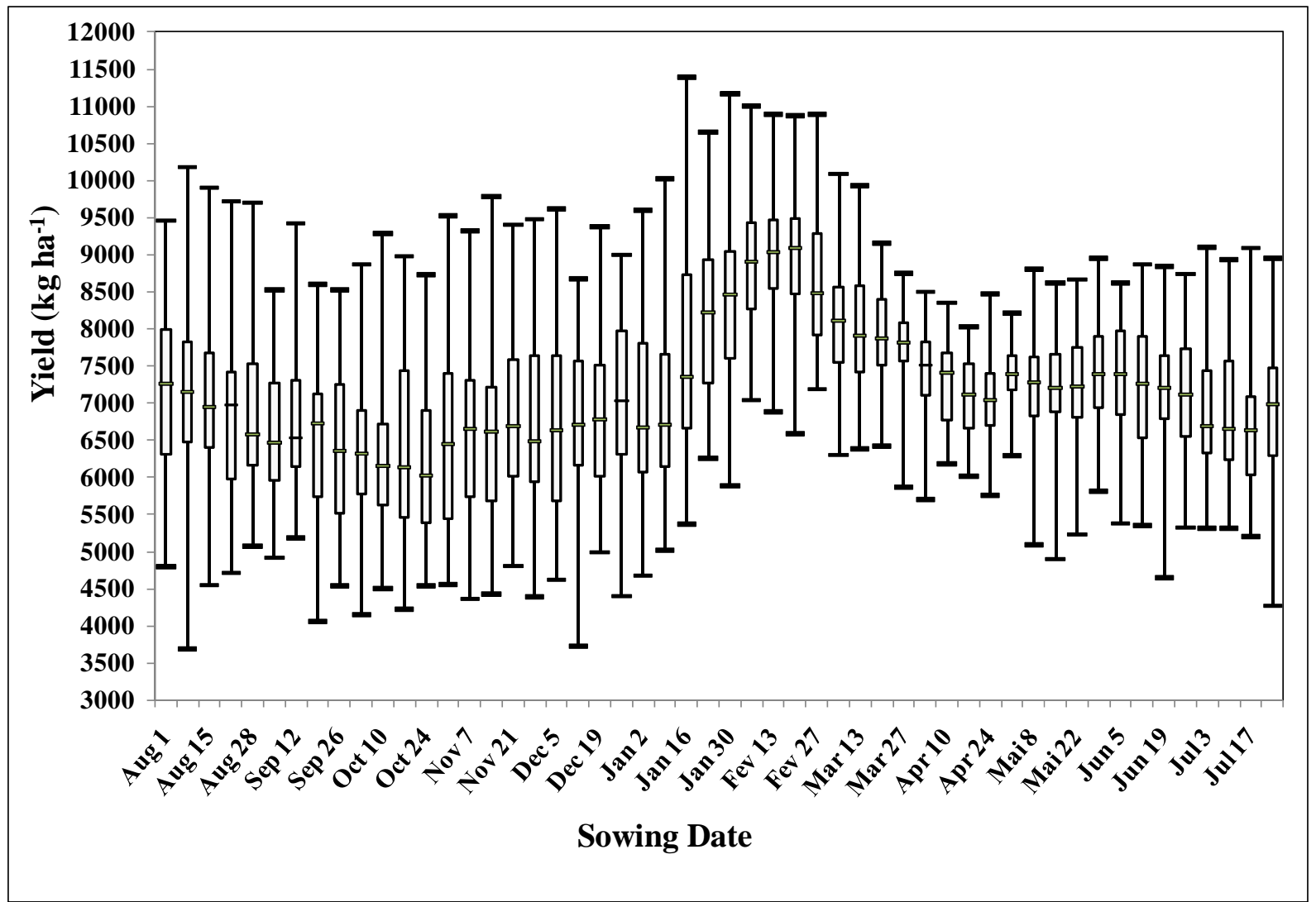

Figure 6. Frequency distribution of simulated maize grain yield, indicating minimum, maximum, median and percentiles, for different sowing dates, under irrigation conditions at Riacho's Farm. Matozinhos, MG, Brazil.

Those figures are within the yield range obtained by Cruz et al. (2005; 2009), for the same cultivar, grown in field trials in Sete Lagoas, MG, Brazil, although they are higher than the values reported by the cultivar developer (Dekalb, 2010) and also much higher than the estimated regional average yields of 2,969 to $4,350 \mathrm{kgha}^{-1}$ for rainfed maize production from 2003 to 2008 cropping seasons (IBGE, 2010).

Some of the sowing dates, such as May $1^{\text {st }}$, presented lower yield amplitude as compared to the others (Figure 6) and, consequently, smaller variance associated to its yield average (Figure 7), which certainly were also due to a lower interannual weather conditions variability. Low variance was not always associated to high yields, though. There is, however, a group of sowing dates, which clearly provided greater yield with intermediate variances. This information can assist in defining a sowing window, which in that case, would be from February $6^{\text {st }}$ (T28) to $27^{\text {th }}$ (T31). 
February 20th sowing date (T30) provided the highest mean yield of 9,096 kgha-1, corresponding to the average of $9,000 \mathrm{kgha}^{-1}$, which, in turn, is $30.51 \%$ higher than the harvested yield obtained at Riacho's Farm 45 ha center pivot area, for the April 20th, 2008 cropping season. When comparing simulated grain yield averages for February 20th sowing date (T30) with that for October 17th (T12), both under supplemental irrigation, there was 2,644 $\mathrm{kgha}^{-1}$ or $41.60 \%$ advantage for planting in February. On the other hand, when comparing simulated average grain yield of 9,000 kgha-1 for February 20th sowing date (T30), under irrigation, with the $3,384 \mathrm{kgha}^{-1}$ (data not shown), obtained for the same sowing date, but rainfed, one could verify the importance of irrigation as a strategy to improve grain production in that region of Minas Gerais State, Brazil.

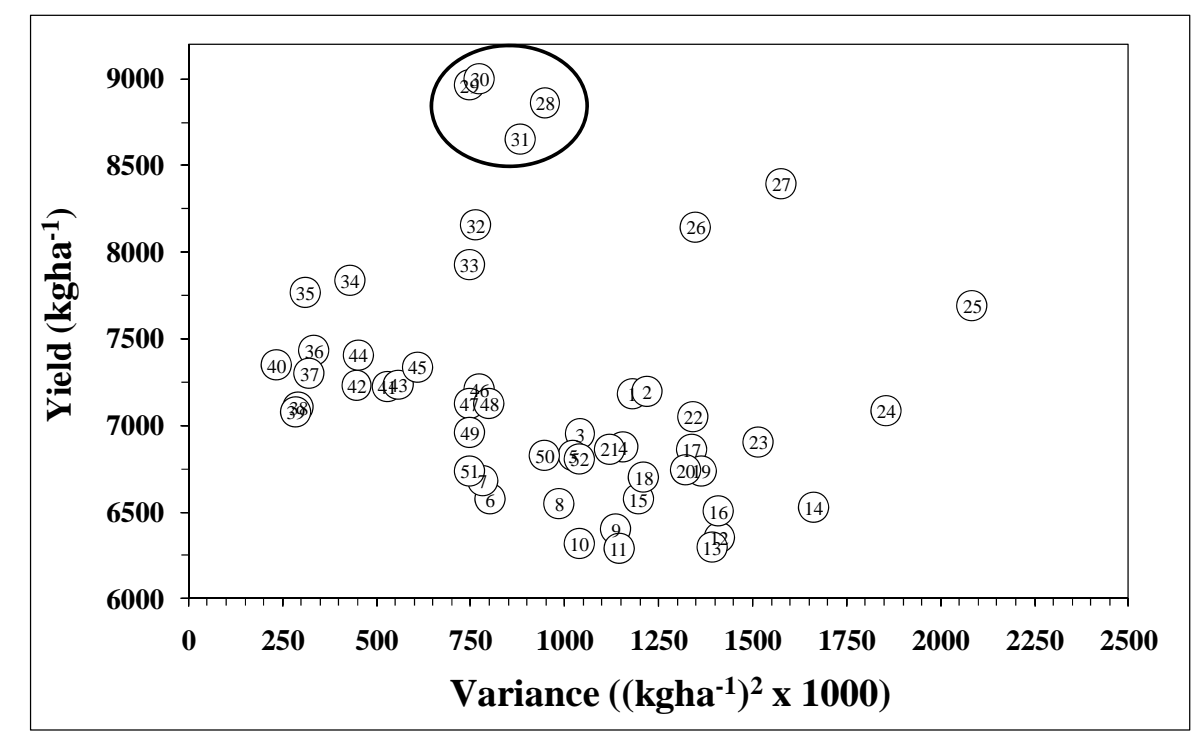

Figure 7. Variance of associated to average grain yield, for different sowing dates (circles) at Riacho's Farm. Matozinhos, MG, Brazil.

Obviously, one should consider whether the grain yield increment would be justified, considering water and energy consumption issues (Andrade et al., 2011) and profitability. October $17^{\text {th }}$ sowing date was considered one of the best planting dates for rainfed maize production in the region (Andrade et al., 2009).

Although the plots generated by the model (Figures 6 and 7) can assist in defining the sowing window, the decision is still not simple and is somehow arbitrary. A percent yield break curve (Andrade et al., 2009; Amaral et al., 2009) was generated for Riacho's Farm (Figure 8).

February $20^{\text {th }}$ (T30) was the sowing date that provided the highest average yield, 9,000 $\mathrm{kgha}^{-1}$, which was used as reference to calculate yield break percentage. There was a period in which yield break, due to sowing in dates different from the best one, can be considered acceptable by the decision-maker, allowing one to define a sowing window. The decisionmaker, being it a farmer, extension officer or consultant, can decide what level of yield reduction would be tolerable and, then, set your planting period. If, for instance, the decisionmaker would be willing to accept up to $5 \%$ average yield break, the sowing window would be February $6^{\text {th }}$ (T28) to $27^{\text {th }}$ (T31). In addition, if a $10 \%$ yield break would be acceptable, the sowing window would be extended from January $23^{\text {rd }}$ (T26) to March $6^{\text {th }}$ (T32) (Figure 8). 


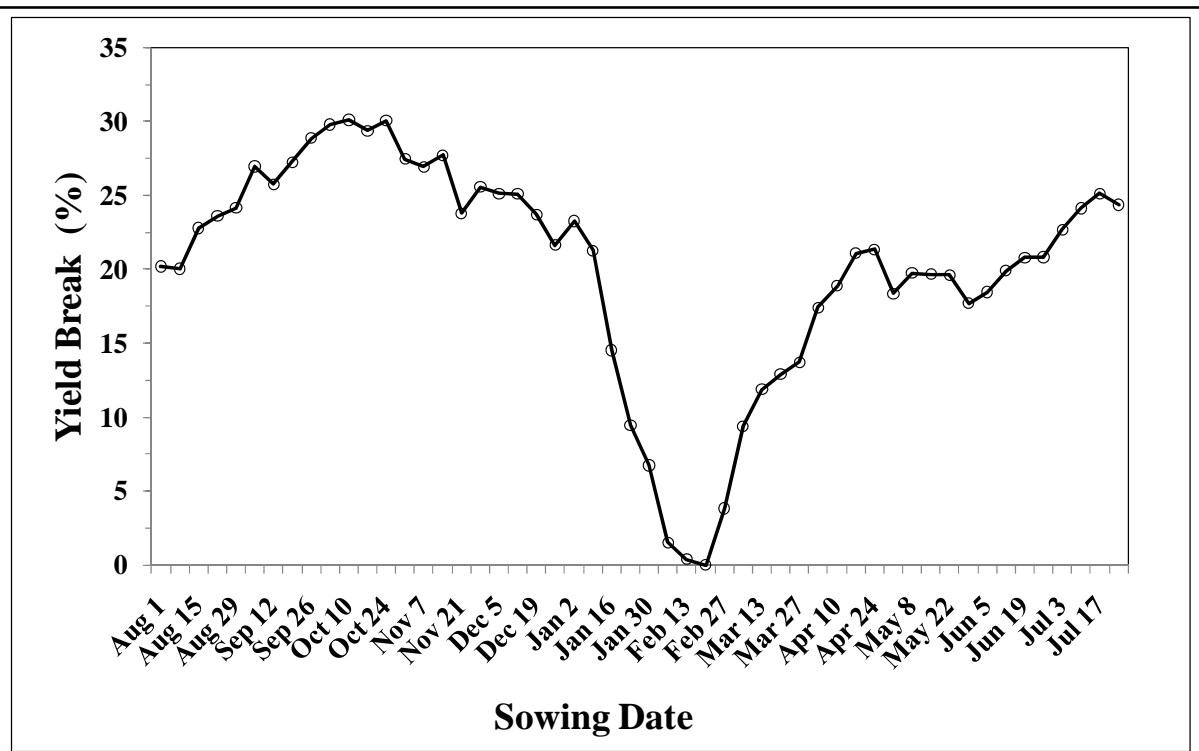

Figure 8. Average maize grain yield break for different sowing dates. Riacho's Farm. Matozinhos, MG, Brazil.

\subsection{Climate thermal conditions effect on crop yield}

Even when the crop was maintained under adequate soil moisture conditions, through automatic irrigation, one can observe seasonal and interannual variation in grain yield, with considerable amplitudes among maximum and minimum values, for most of the sowing dates, indicating that factors, other than water stress can significantly affect crop yield (Figure 6).

For February $20^{\text {th }}$ sowing date (T30), the 1963 season provided the highest yield, 10,872 $\mathrm{kgha}^{-1}$, while the lowest yield, 6,585 $\mathrm{kgha}^{-1}$, was obtained in 1999, a 39.4\% decrease. Since there were no water supply restrictions, the difference in yield was due to other factors, among them, the prevailing thermal regime during crop cycle in these two years.

In 1963, observed minimum temperatures were lower and temperature amplitude higher than in 1999 (Figures 9 and 10), extending the crop cycle. Similar results were found by Soler et al. (2007), when differences in temperature associated with differences in other weather variables explained, in part, the differences in yield between the two irrigated experiments that were conducted in different years.

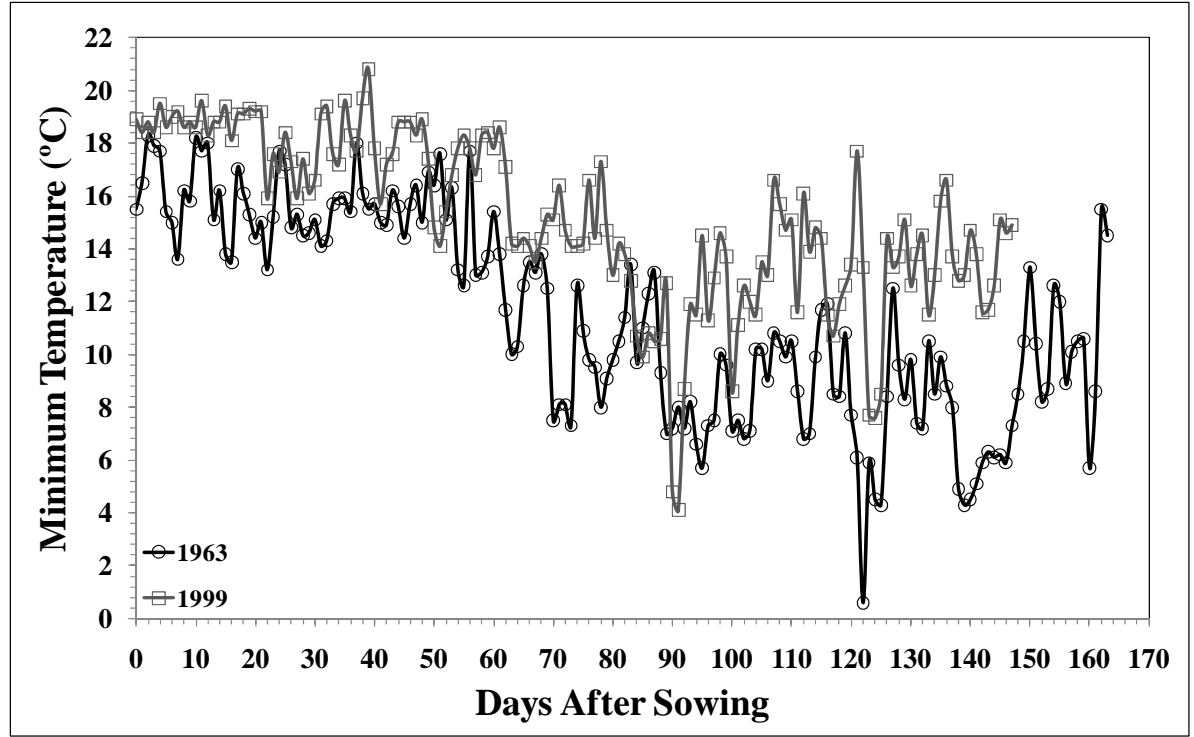

Figure 9. Observed minimum temperature along crop cycle for February $20^{\text {th }}$ sowing date of 1963 and 1999 cropping seasons. Sete Lagoas, MG, Brazil. 
Simulated time from sowing to anthesis was 64 days after sowing (DAS) for both years, while crop cycle, from sowing to physiological maturity, was 147 DAS in 1999 and 163 DAS in 1963 (Figure 11). This is in accordance to what is reported in literature, regarding maize physiological response to thermal effects. According to Fancelli (2000), maximum solar radiation conversion efficiency is affected by prevailing day and night time period temperature and the resulting temperature amplitude. Thus, relatively high daytime temperatures allow high photosynthetic rates, while mild night temperatures contribute to extend growth period and to reduce maintenance respiration, ensuring the crop more days for effective incident solar radiation use (Didonet et al., 2001). The combination of longer crop cycle with lower night temperature led to higher yield in 1963, agreeing to what was reported by Fancelli and Dourado-Neto (2000).

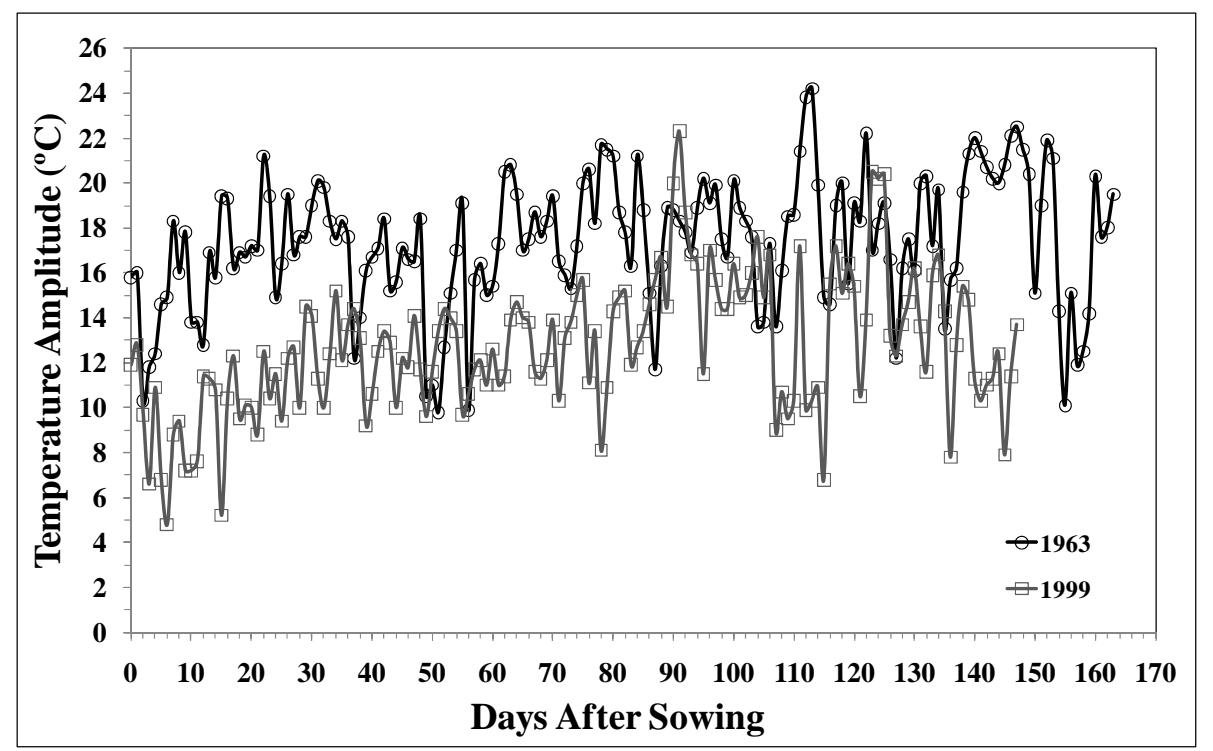

Figure 10. Observed temperature amplitude observed during crop cycle for February $20^{\text {th }}$ sowing date of 1963 and 1999 cropping seasons. Sete Lagoas, MG, Brazil.

Maize growth stages lengths are controlled mainly by the environment thermal conditions. Plant shifts to another stage only after a certain thermal sum occurs. Observed thermal sum from sowing to anthesis was 875 degree-days (DD) for 1963 season and 880 DD for 1999 (Figure 11); values very close to the 870 DD reported for cultivar DKB 390YG (Dekalb, 2010). On the other hand, in 1963 it took 163 days after sowing (DAS) for the crop to cumulate $1669 \mathrm{DD}$, while in 1999 it required only 147 DAS to add up 1709 DD. In other words, maize crop was not influenced by the thermal regime until it reached anthesis. After that, in mild years, it took more days to cumulate degree-days and complete its physiological cycles.

Although temperature and water stress are the main factors that influence plant growth and development, solar radiation is also essential, since it controls the photomorphogenic and photosynthetic processes that are responsible for carbohydrates production and accumulation in the leaves, which are later translocated to grains (Kunz et al., 2007). According to Magalhães et al. (2002), light deficiency occurring at critical periods, as the grain filling phase, is one of the reasons for reduction in maize yield. One can observe that observed average daily solar radiation values, for each one of the crop phases studied, were a little higher in 1963 season, as compared to 1999 (Table 3). However, in 1963 observed cumulative solar radiation was considerable higher than in 1999, for the three crop phases. The combination of high daylight (Figure 10) with low nighttime temperatures (Figure 9), leading 
to longer cycle (Figure 10) and higher cumulated solar radiation in 1963 season (Table 3), provided adequate conditions for higher maize grain yield in that year. This is in agreement with what was reported by Didonet et al. (2002) and Freitas et al. (2001).

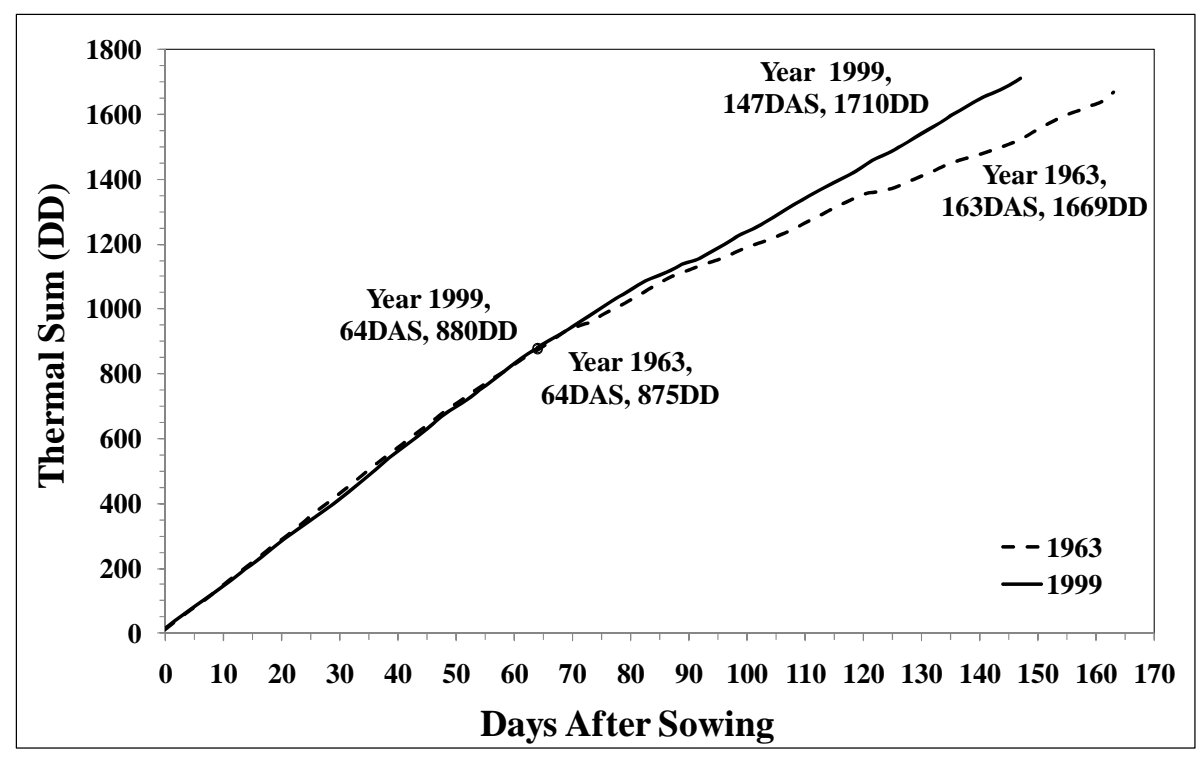

Figure 11. Thermal sum, expressed in degree-days (DD), along maize crop cycle for 1963 and 1999 cropping seasons. Sete Lagoas, MG, Brazil.

Table 3. Observed average and cumulative solar radiation for different developmental stages of maize.

\begin{tabular}{|c|c|c|c|}
\hline Developmental Stages & Solar Radiation & 1963 & 1999 \\
\hline \multirow{5}{*}{$\begin{array}{c}\text { Emergence to } \\
\text { Physiological Maturity }\end{array}$} & Total $\left(\mathrm{MJm}^{-2}\right)$ & $3,100.90$ & $2,659.50$ \\
\hline & Average $\left(\mathrm{MJm}^{-2} \mathrm{~d}^{-1}\right)$ & 18.91 & 17.97 \\
\hline & Standard Deviation & 4.15 & 3.80 \\
\hline & Maximum $\left(\mathrm{MJm}^{-2} \mathrm{~d}^{-1}\right)$ & 28.70 & 25.80 \\
\hline & $\operatorname{Minimum}\left(\mathrm{MJm}^{-2} \mathrm{~d}^{-1}\right)$ & 6.70 & 7.00 \\
\hline \multirow{5}{*}{ Emergence to Anthesis } & Total $\left(\mathrm{MJm}^{-2}\right)$ & $1,428.30$ & $1,283.40$ \\
\hline & Average $\left(\mathrm{MJm}^{-2} \mathrm{~d}^{-1}\right)$ & 21.97 & 19.74 \\
\hline & Standard Deviation & 4.28 & 4.10 \\
\hline & Maximum $\left(\mathrm{MJm}^{-2} \mathrm{~d}^{-1}\right)$ & 28.70 & 25.80 \\
\hline & Minimum $\left(\mathrm{MJm}^{-2} \mathrm{~d}^{-1}\right)$ & 10.20 & 10.50 \\
\hline \multirow{5}{*}{$\begin{array}{c}\text { Anthesis to Physiological } \\
\text { Maturity }\end{array}$} & Total $\left(\mathrm{MJm}^{-2}\right)$ & $1,672.60$ & $1,376,10$ \\
\hline & Average $\left(\mathrm{MJm}^{-2} \mathrm{~d}^{-1}\right)$ & 16.89 & 16.58 \\
\hline & Standard Deviation & 2.52 & 2.89 \\
\hline & Maximum $\left(\mathrm{MJm}^{-2} \mathrm{~d}^{-1}\right)$ & 20.70 & 21.40 \\
\hline & Minimum $\left(\mathrm{MJm}^{-2} \mathrm{~d}^{-1}\right)$ & 6.70 & 7.00 \\
\hline
\end{tabular}

\section{CONCLUSIONS}

The CSM-CERES-Maize proves to be an interesting tool to assist in decision making regarding crop and irrigation management of irrigated maize. The model is also a useful means to investigate climate variability effects on maize yield. There is a large seasonal and interannual variability in simulated maize crop yield, even under irrigated conditions. A maize grain yield break curve, derived for the Riacho's Farm conditions, provides to the farm's manager information to make decisions based on the risk one would be willing take. Assuming a $10 \%$ break in relation to a maximum average expected yield, one can establish a sowing window for irrigated maize, which extends from January $23^{\text {rd }}$ to March $6^{\text {th }}$, with February $20^{\text {th }}$, being the best sowing date. 


\section{ACKNOWLEDGEMENTS}

The authors would like to express thanks to the State of Minas Gerais Research Support Agency, FAPEMIG, for partially supporting this work through the research grant proposal number EDT 2997/06. We also wish to thank Embrapa, for the personnel and logistics support during data collection, to Mr. Arlindo Marcelo dos Reis, manager of Riacho Farm, for providing data for modeling verification, and to Mr. José dos Santos Evódio, from Minas Gerais State Extension Service Agency, EMATER-MG, for mediating contact with famers.

\section{REFERENCES}

Anuário da Agricultura Brasileira - AGRIANUAL. São Paulo: Instituto FNP, 2008. 520 p.

AMARAL, T. A.; ANDRADE, C. de L. T. de; OLIVEIRA, A. C. de; SILVA, D. de F.; SANTANA, C. B. de; MOURA, B. F. et al. Metodologia para o estabelecimento do período de semeadura de milho. Sete Lagoas: Embrapa Milho e Sorgo, 2009. 13 p. (Documentos, 88).

ANDRADE, C. L. T.; AMARAL, T. A.; ALVES. M. E. B.; SILVA, D. F. Temporal variability of water requirement and productivity for irrigated maize crop. Ambiente \& Água, Taubaté, v.6, n. 2, p.54-60, 2011. http://dx.doi.org/10.4136/ambi-agua.185

ANDRADE, C. L. T.; AMARAL, T. A.; SILVA, D. F.; GARCIA, A. G. Y.; HOOGENBOOM, G.; GUIMARAES, D. P. et al. Utilização do modelo CERES-maize como ferramenta na definição de estratégias de semeadura de milho: 2 sistema de produção irrigado. In: CONGRESSO BRASILEIRO DE AGROMETEOROLOGIA, 16., 2009, Belo Horizonte. Mudanças climáticas, recursos hídricos e energia para uma agricultura sustentável. Resumos... Belo Horizonte: SBA; Viçosa, MG: UFV; Sete Lagoas: Embrapa Milho e Sorgo, 2009.

BERGONCI, J. I.; BERGAMASCHI, H.; SANTOS, A. O.; FRANÇA, S.; RADIN, B. Eficiência da irrigação em rendimento de grãos e matéria seca de milho. Pesquisa Agropecuária Brasileira, Brasília, v. 36, p. 949-956, 2001.

CRUZ, J. C.; MONTEIRO, M. A. R.; LOUREIRO, J. E.; PEREIRA FILHO, I. A.; NOCE, M. A.; VIANA, A. C. et al. Avaliação de cultivares de milho na região de Sete Lagoas, MG. Sete Lagoas: Embrapa Milho e Sorgo, 2005. 6 p. (Circular técnica, 65).

CRUZ, J. C.; GARCIA, J. C.; GOMES, P. H. A.; FERNANDES, J. S. C.; ALBERNAZ, W. M. Avaliação de sistemas de produção de milho na região de Sete Lagoas, MG. Sete Lagoas: Embrapa Milho e Sorgo, 2009. 6 p. (Circular técnica, 123).

DIDONET, A. D.; RODRIGUES, O.; MARIO, J. L.; IDE, F.; TISSOT, D. Crescimento e desenvolvimento de milho: acúmulo de massa seca do grão. Pesquisa Agropecuária Brasileira, Brasília, v. 36, n. 3, p. 447-456, mar. 2001.

DIDONET, A. D.; RODRIGUES, O.; MARIO, J. L.; IDE, F. Efeito da radiação solar e temperatura na definição do número de grãos em milho. Pesquisa Agropecuária Brasileira, Brasília, v. 37, p. 933-938, 2002.

DEKALB. Semente híbrida de milho safrinha 2007 DKB 390. Available at: <http://www.dekalb.com.br/produto_milho_safrinha.aspx?id=34>. Access in: May 26, 2010. 
FANCELli, A. L.; DOURADO-NETO, D. Produção de milho. Guaíba: Agropecuária, Guaíba, 2000. 360 p.

FANCELLI, A. L. Fisiologia, nutrição e adubação do milho para alto rendimento. In: SIMPÓSIO SOBRE ROTAÇÃO SOJA/MILHO NO PLANTIO DIRETO, 1., 2000, Piracicaba. Available at: <http://www.ipni.net/ppiweb/pbrazil.nsf/926048f0196c9d 4285256983005c64de/7ac877864218d46983256c70005790fc/\$FILE/Anais\%20Antonio \%20Luiz\%20Fancelli.doc>. Access in: January 04, 2011.

FORSTHOFER, E. L.; SILVA, P. R. F.; STRIEDER, M. L.; MINETTO, T.; RAMBO, L.; ARGENTA, G. et al. Desempenho agronômico e econômico do milho em diferentes níveis de manejo e épocas de semeadura. Pesquisa Agropecuária Brasileira, Brasília, v. 41, n. 3, p. 399-407, mar. 2006.

FREITAS, P. S.; MANTOVANI, E. C.; REZENDE, R.; GONÇALVES, A. C. A.; BERTONHA, A. Influência da radiação solar sobre os valores de produtividade da cultura do milho, Zea mays L., simulados pelo modelo CERES-Maize. Acta Scientiarum, Maringá, v. 23, n. 5, p. 1221-1227, 2001.

HOOGENBOOM, G.; JONES, J. W.; WILKENS, P. W.; PORTER, C. H.; BOOTE, K. J.; HUNT, L. A. et al. Decision Support System for Agrotechnology Transfer (DSSAT) Version 4.5. Honolulu: University of Hawaii, 2010. 1 CD-ROM.

HUNT, L. A.; BOOTE, K. J. Data for model operation, calibration and evaluation. IN: TSUJI, G. Y.; HOOGENBOOM, G.; THORTHON, P. K. Understanding options for agricultural production. Dordrech: Kluwer Academic Publishers, 1998. p. 9-40.

INSTITUTO BRASILEIRO DE GEOGRAFIA E ESTATÍSTICA. Sistema IBGE de Recuperação Automática-SIDRA: tabela 839: área plantada, área colhida, quantidade produzida e rendimento médio de milho, $1^{\mathrm{a}}$ e $2^{\mathrm{a}}$ safras. Available at: $<$ http://www.sidra.ibge.gov.br/bda/tabela/listabl.asp?c=839\&z=t\&o=11>. Access in: October 20, 2010.

KASELE, I. N.; NYIRENDA, F.; SHANAHAN, J. F.; NIELSEN, D. C.; D’ANDRIA, R. Ethephon alters corn growth, water use, and grain yield under drought stress. Agronomy Journal, Madison, v. 86, p. 283- 288, 1994. http://dx.doi.org/10.2134/agronj1994.00021962008600020014x

KINIRY, J. R.; WILLIAMS, J. R.; VANDERLIP, R. L.; ATWOOD, J. D.; REICOSKY, D. C.; MULLIKEN, J. et al. Evaluation of two maize models for nine U.S. locations. Agronomy Journal, Madison, v. 89, p. 421-426, 1997. http://dx.doi.org/10.2134/agronj1997.00021962008900030009x

KOZLOWSKI, L. A. Período crítico de interferência das plantas daninhas na cultura do milho baseado na fenologia da cultura. Planta Daninha, Viçosa, v. 20, n. 3, p. 365-372, 2002.

KUNZ, J. H.; BERGONCI, J. I.; BERGAMASCHI, H.; DALMAGO, G. A.; HECKLER, B. M. M.; COMIRAN, F. Uso da radiação solar pelo milho sob diferentes preparos do solo, espaçamento e disponibilidade hídrica. Pesquisa Agropecuária Brasileira, Brasília, v. 42, n. 11, p. 1511-1520, nov. 2007.

LOZADA, B. I.; ANGELOCCI, L. R. Efeito da temperatura do ar e da disponibilidade hídrica do solo na duração de subperíodos e na produtividade de um híbrido de milho. Revista Brasileira de Agrometeorologia, Santa Maria, v. 7, n. 1, p. 37-43, 1999. 
MAGALHÃES, P. C.; DURÃES, F. O. M.; CARNEIRO, N. P.; PAIVA, E. Fisiologia do milho. Sete Lagoas: Embrapa Milho e Sorgo, 2002. 23 p. (Circular técnica, 22).

SANTANA, C. B. de; ANDRADE, C. de L. T. de; AMARAL, T. A.; SILVA, D. de F.; MOURA, B. F.; CASTRO, L. A. de. Parametrização do modelo Ceres-Maize para cultivares de milho. In: SEMINÁRIO DE INICIAÇÃO CIENTÍFICA PIBIC/BIC JÚNIOR, 1., 2010, Sete Lagoas. Trabalhos apresentados... Sete Lagoas: Embrapa Milho e Sorgo, 2010. 1 CD-ROM.

SILVA, P. R. F.; ARGENTA, G.; REZERA, F. Resposta de híbridos de milho irrigado à densidade de plantas em três épocas de semeadura. Pesquisa Agropecuária Brasileira, Brasília, v. 34, n. 4, p. 585-592, abr. 1999.

SOLER, C. M. T.; HOOGENBOOM, G.; SENTELHAS, P. C.; DUARTE, A. P. Impact of water stress on maize grown off-season in a subtropical environment. Journal of Agronomy and Crop Science, Berlin, v. 193, p. 247-261, 2007.

http://dx.doi.org/10.1111/j.1439-037X.2007.00265.x

WALLACH, D. Evaluating crop models. In: WALLACH, D.; MAKOWSKI, D.; JONES, J. W. Working with dynamic crop models: evaluation, analysis, parameterization and applications. Amsterdam: Elsevier, 2006. p.11-54.

WILSON, D. R.; MUCHOW, R. C.; MURGATROYD, C. J. Model analysis of temperature and solar radiation limitations to maize potential productivity in a cool climate. Field Crops Research, Amsterdam, v. 43, p. 1-18, 1995.

http://dx.doi.org/10.1016/0378-4290(95)00037-Q 